\title{
Response of Soil Application of Diatomaceous Earth as a Source of Silicon on Leaf Nutrient Status of Guava
}

\author{
Kishore Kumar Das ${ }^{1 *}$, G.S.K. Swamy ${ }^{2}$, Debalina Biswas ${ }^{3}$ and Kuldeep Kumar Chnaniya ${ }^{4}$ \\ ${ }^{1}$ Swami Keshwanand Rajasthan Agriculture University, Bikaner- 334006, Rajasthan \\ ${ }^{2}$ College of Horticulture, Mysore- 571130, Karnataka, India \\ ${ }^{3}$ ICAR Research Complex for North East Region, Barapani- 793103, Meghalaya, India \\ ${ }^{4}$ Swami Keshwanand Rajasthan Agriculture University, Bikaner- 334006, Rajasthan, India \\ *Corresponding author
}

\section{A B S T R A C T}

\section{Keywords}

Diatomaceous

Earth (DE), Silicon,

Macro nutrient,

Micronutrient.

Article Info

Accepted:

12 March 2017

Available Online:

10 April 2017
An experiment was carried out in Kittur Rani Channamma College of Horticulture, Arabhavi, Belgaum District, Karnataka state to know the response of soil application of diatomaceous earth (DE) as a source of silicon on leaf nutrient status of guava. Leaf sample under different treatment were collected and utilized for analysis of nutrient status. The highest macronutrient viz., Nitrogen (2.13\%), Phosphorous $(0.32 \%)$ and Potassium $(0.65 \%)$ were recorded in plants applied with Half of RDF, Recommended dose of fertilizer (RDF), Half of RDF, RDF $+1 \mathrm{~kg} /$ plant of DE, and RDF $+3 \mathrm{~kg} /$ plant of DE and $\mathrm{RDF}+3 \mathrm{~kg} /$ plant of DE respectively. The Micronutrients of guava leaves viz., Calcium (1.39\%), Magnesium (0.44\%), Zinc (77.55 ppm), Iron(136.58), Silicon (0.45\%), manganese (260.53), and Copper $(67.45 \mathrm{ppm})$ were also recorded in plants applied with $\mathrm{RDF}+3 \mathrm{~kg} /$ plant DE.

\section{Introduction}

The crop production of guava can be increased by balanced nutrition on profitable basis even though it is growing in the tropical condition. The growth, yield and quality of guava can be increased by application of manures and fertilizers as it respond to application of fertilizers. Among the plants, silicon concentration is found to be higher in monocotyledons than in dicotyledons and its level increased from legumes < fruit crops < vegetables < grasses < grain crops. The role of silicon in plant biology is to reduce multiple stresses including biotic and abiotic stresses. It is also known to increase drought tolerance in plants by maintaining plant water balance, photosynthetic activity, erectness of leaves and structure of xylem vessels under high transpiration rates (Melo et al., 2003). Silicon application improved water economy and dry matter yield (Gong et al., 2003). It enhanced the leaf water potential under water stress conditions, reduced the incidence of micronutrient and metal toxicity (Matoh et al., 1991). The presence of Silicon also been reported to affect the absorption and translocation of several macro and micronutrients. Si is accumulated in plants to total concentrations in dry matter similar to those of essential macro-nutrients such as Potassium, Calcium, Magnesium, Sulphur and 
Phosphorous (Epstein, 1999). More recently, silicon amendments were shown to reduce the leaching of phosphate, nitrate and potassium (Matichenkov and Bocharnikova, 2010).

With this brief information and based on the possible benefits of silicon, the present study was carried out to know the Response of Soil Application of Diatomaceous Earth as a Source of Silicon on Leaf Nutrient Status of Guava.

\section{Materials and Methods}

Experiment was carried out in an established guava orchard of 6 years old plants with spacing of $6 \mathrm{~m} \times 6 \mathrm{~m}$. The source of silicon used is Diatomaceous earth (DE), applied as basal dose to the respective treatment in this experiment. The dosage of DE used in this experiment was 1, 2 and $3 \mathrm{~kg} / \mathrm{plant}$.

The inorganic nutrient i.e. nitrogen was applied in the form of urea $(46 \% \mathrm{~N})$, phosphorous in the form of single super phosphate and potassium in the form of muriate of potash $(60 \% \mathrm{~K})$. These nutrients were applied to the respective treatment according to the package of practice of UHS; Bagalkot (200:80:150g NPK/plant), (Anon, 2015). The design adopted for the experiment was Randomized Block Design (RBD) with nine treatments and three replications. The treatments are

$\mathrm{T}_{1}$ - Absolute control,

$\mathrm{T}_{2}$ - Recommended dose of fertilizer (RDF) @ 200:80:150 g NPK/plant,

$\mathrm{T}_{3}$ - Half of RDF,

$\mathrm{T}_{4}-$ Half of $\mathrm{RDF}+1 \mathrm{~kg} /$ plant of Diatomaceous Earth (DE), $\mathrm{T}_{5}-$ Half of RDF $+2 \mathrm{~kg} / \mathrm{plant}$ of $\mathrm{DE}$, $\mathrm{T}_{6}-$ Half of $\mathrm{RDF}+3 \mathrm{~kg} /$ plant of $\mathrm{DE}$, $\mathrm{T}_{7}-\mathrm{RDF}+1 \mathrm{~kg} /$ plant of DE, $\mathrm{T}_{8}-\mathrm{RDF}+2 \mathrm{~kg} /$ plant of $\mathrm{DE}$, $\mathrm{T}_{9}-\mathrm{RDF}+3 \mathrm{~kg} /$ plant of $\mathrm{DE}$

\section{Leaf sampling and processing}

Leaf samples were collected from the designated plants of Leaf samples ( $8^{\text {th }}$ leaf) of each treatment in each replication after 4 months of bahar treatment. After cleaning with distilled water, leaf samples were ovendried at $50^{\circ} \mathrm{C}$ till they attain constant weight and analysed for nutrient status. The samples were analysed for total nitrogen, phosphorous, potassium, and micronutrients like, Calcium Magnesium, Zinc, Iron, Silicon, manganese, and Copper content. Estimation of total nitrogen, phosphorous and potassium were analysed as per the procedure given by Jackson, 1967. Calcium and magnesium were analysed as per the procedure given by titration with EDTA (disodium di hydrogenethylene diamine tetraacetate) which was reported by Tucker and Kurtz (1960). Zinc and Copper content was estimated by Diethylene triamine pentaacetic acid (DTPA) method (Lindasayand Norwell, 1978). Silicon content was estimated by ANSA (1-amino-2napthol-4-sulfonic acid) method (Kadalli et al., 2013).

\section{Results and Discussion}

Effect of different treatments on nutrient content of leaves viz., nitrogen, phosphorus, potassium, calcium, magnesium, zinc, iron and silica are presented in tables 1 and 2 . The Nitrogen content in leaf was found nonsignificant in all the treatments. The higher value recorded in $\mathrm{T}_{3}(2.16)$ and least the value recorded in $\mathrm{T}_{6}$ (2.07). In case of Phosphorus content in leaf was found non significant. However higher value was recorded $\operatorname{inT}_{2}, \mathrm{~T}_{3}$ $\mathrm{T}_{7}$ and $\mathrm{T}_{9}(0.32)$ and the least value was recorded in $\mathrm{T}_{1}$ and $\mathrm{T}_{6}(0.29 \%)$. And also potassium content in guava leaves, there was non-significant difference among the different treatments. The maximum potassium content $(0.65 \%)$ was observed in $\mathrm{T}_{9}(\mathrm{RDF}+3$ $\mathrm{kg} /$ plant of DE), While minimum potassium content $(0.56 \%)$ was observed in $\mathrm{T}_{1}$. 
Table.1 Effect of diatomaceous earth (DE) on macro nutrient content of guava leaf

\begin{tabular}{|c|c|c|c|}
\hline Treatments & $\mathbf{N}(\%)$ & $\mathbf{P}(\%)$ & $\mathbf{K}(\%)$ \\
\hline$T_{1}$ - Absolute control & 2.14 & 0.29 & 0.56 \\
\hline$T_{2}$ - Recommended dose of fertilizer (RDF) & 2.15 & 0.32 & 0.60 \\
\hline$T_{3}$ - Half of Recommended dose of fertilizer & 2.16 & 0.32 & 0.60 \\
\hline$T_{4}-$ Half of $R D F+1 \mathrm{~kg} /$ plant of $\mathrm{DE}$ & 2.13 & 0.30 & 0.63 \\
\hline$T_{5}-$ Half of $R D F+2 \mathrm{~kg} /$ plant of $\mathrm{DE}$ & 2.12 & 0.30 & 0.62 \\
\hline$T_{6}-$ Half of RDF $+3 \mathrm{~kg} /$ plant of $\mathrm{DE}$ & 2.07 & 0.29 & 0.61 \\
\hline $\mathrm{T}_{7}-\mathrm{RDF}+1 \mathrm{~kg} / \mathrm{plant}$ of DE & 2.09 & 0.32 & 0.61 \\
\hline $\mathrm{T}_{8}-\mathrm{RDF}+2 \mathrm{~kg} /$ plant of DE & 2.11 & 0.30 & 0.54 \\
\hline $\mathrm{T}_{9}-\mathrm{RDF}+3 \mathrm{~kg} / \mathrm{plant}$ of $\mathrm{DE}$ & 2.13 & 0.32 & 0.65 \\
\hline \multicolumn{4}{|l|}{ S.Em \pm} \\
\hline CD@ $9 \%$ & N.S & N.S & N.S \\
\hline
\end{tabular}

N.S- Non significant 
Table.2 Effect of diatomaceous earth (DE) on micro nutrient content of guava leaf

\begin{tabular}{|c|c|c|c|c|c|c|c|}
\hline Treatments & $\mathrm{Ca}(\%)$ & $\operatorname{Mg}(\%)$ & Zn (ppm) & Fe (ppm) & Si (ppm) & $\operatorname{Mn}(\mathbf{p p m})$ & $\mathrm{Cu}(\mathbf{p p m})$ \\
\hline $\mathbf{T}_{1}$ - Absolute control & 0.86 & 0.28 & 11.31 & 135.02 & 0.20 & 160.31 & 37.41 \\
\hline$T_{2}$ - Recommended dose of fertilizer (RDF) & 0.94 & 0.31 & 11.81 & 117.53 & 0.22 & 181.63 & 30.73 \\
\hline$T_{3}$ - Half of Recommended dose of fertilizer & 1.00 & 0.35 & 14.20 & 137.38 & 0.23 & 172.18 & 48.20 \\
\hline$T_{4}-$ Half of RDF + 1kg/plant of DE & 1.10 & 0.37 & 12.83 & 134.78 & 0.32 & 221.38 & 65.18 \\
\hline$T_{5}-$ Half of RDF $+2 \mathrm{~kg} / \mathrm{plant}$ of $\mathrm{DE}$ & 1.18 & 0.37 & 16.06 & 124.71 & 0.30 & 218.50 & 33.48 \\
\hline$T_{6}$ - Half of RDF + 3kg/plant of DE & 1.07 & 0.33 & 15.83 & 121.15 & 0.33 & 232.40 & 53.33 \\
\hline $\mathrm{T}_{7}-\mathrm{RDF}+1 \mathrm{~kg} /$ plant of DE & 1.22 & 0.36 & 16.20 & 113.78 & 0.29 & 239.76 & 61.48 \\
\hline$T_{8}-R D F+2 \mathrm{~kg} / \mathrm{plant}$ of DE & 1.20 & 0.41 & 15.70 & 110.56 & 0.28 & 240.87 & 62.86 \\
\hline$T_{9}-$ RDF + $3 \mathrm{~kg} /$ plant of DE & 1.39 & 0.44 & 17.55 & 136.58 & 0.45 & 260.53 & 67.45 \\
\hline S.Em \pm & 0.04 & 0.02 & 0.53 & & 0.03 & 2.10 & 6.45 \\
\hline CD@ 5\% & 0.10 & 0.06 & 1.59 & N.S & 0.10 & 6.31 & 19.35 \\
\hline
\end{tabular}

N.S- Non significant 
Micronutrients of guava leaves viz., Calcium, Magnesium, Zinc, manganese, and Copper, there was significant difference among the different treatments. The maximum calcium content $(1.39 \%)$ was observed in $\mathrm{T}_{9}(\mathrm{RDF}+$ $3 \mathrm{~kg} /$ plant of DE), which was followed by treatment $\mathrm{T}_{7}(1.22 \%)$, while minimum calcium content $(0.86 \%)$ was observed in $\mathrm{T}_{1}$ and it was found on par with $\mathrm{T}_{2}(0.94 \%)$. The maximum magnesium content $(0.44 \%)$ was observed in $\mathrm{T}_{9}(\mathrm{RDF}+3 \mathrm{~kg} /$ plant of $\mathrm{DE})$, while minimum magnesium content $(0.28 \%)$ was observed in $T_{1}$. In case of zinc content of guava leaf the maximum zinc content $(17.55$ ppm) was observed in $\mathrm{T}_{9}(\mathrm{RDF}+3 \mathrm{~kg} / \mathrm{plant}$ of $\mathrm{DE})$, which was on par with treatment $\mathrm{T}_{7}$ (16.20ppm), and $\mathrm{T}_{5}$ (16.06 ppm). While minimum zinc content (11.31ppm) was observed in $T_{1}$ which was found on par with $\mathrm{T}_{2}(11.81 \mathrm{ppm})$. The maximum copper content (67.45ppm) was observed in $\mathrm{T}_{9}(\mathrm{RDF}+3 \mathrm{~kg} /$ plant of DE), which was on par with treatment $\mathrm{T}_{4}(65.18 \mathrm{ppm}), \mathrm{T}_{8}(62.86 \mathrm{ppm})$ and $\mathrm{T}_{7}$ (61.48ppm) while minimum copper content (30.73ppm) was observed in $T_{2}$ which is found on par with $\mathrm{T}_{5}$ (33.48ppm) and the Manganese content of leaves also found significant and the maximum content of manganese (260.53ppm) was noticed in treatment $\mathrm{T}_{9}(\mathrm{RDF}+3 \mathrm{~kg} /$ plant of $\mathrm{DE})$, followed by $\mathrm{T}_{8}(240.87 \mathrm{ppm})$. While minimum manganese content (160.31 ppm) was observed in treatment $T_{1}$. This is due to silicon helps in more absorption of calcium, magnesium, zinc, manganese, and copper in to the plant tissue. Similar results were noticed by Lalithya et al., (2014) in sapota, Bhavya (2010) in Bangalore Blue grapes, Stamatakis et al., (2003) in tomato and Prado and Natale (2005) in passion fruit, Mary (2005) in rose, Kamenidou and Toddy (2008) in ornamental sunflower, Kamenidou et al., (2009) in zinnia and Kamenidou et al., (2010) in gerbera.

Iron content was found non significant difference among the different treatments with respect to iron content of leaf, however the maximum iron content (137.38 ppm) was observed in $\mathrm{T}_{3}(\mathrm{RDF}+3 \mathrm{~kg} / \mathrm{plant}$ of $\mathrm{DE})$, While minimum iron content (110.56 ppm) was observed in $\mathrm{T}_{8}$.

The maximum silicon content $(0.45 \mathrm{ppm})$ was observed in $\mathrm{T}_{9}(\mathrm{RDF}+3 \mathrm{~kg} /$ plant of $\mathrm{DE})$, which was followed by $\mathrm{T}_{6}(0.33 \mathrm{ppm})$ and $\mathrm{T}_{4}$ $(0.32 \mathrm{ppm})$. While minimum silicon content $(0.20 \mathrm{ppm})$ was observed and it shows significant difference among the different treatments with respect to silicon content of leaf $\mathrm{T}_{1}$. Application of higher dose of Diatomaceous Earth leads to more absorption on silicon by leaves of guava plants. The results are in conformity with findings of Lalithya et al., (2014) in sapota, Bhavya (2010) in Bangalore Blue grapes, Savvas et al., (2009) in tomato, Milne et al., (2012) in lettuce, Kamenidou et al., (2009) in gerbera and Mary (2005) in rose.

\section{References}

Anonymous. 2013. Package of practice of horticulture crops. Pub. UHS, Bagalkot, p. 8.

Bhavya, H.K. 2010. Effect of foliar silicic acid and boron in Bengaluru Blue grapes.M. Sc. (Hort.) Thesis, Univ. Agric. Sci., Bengaluru, p. 95.

Epstein, E., 1999. Silicon-Annual review on plant physiology. Pl. Mol. Biol., 50: 641-644.

Gong, H.J., Chen, K.M., Chen, G.C., Wang, S.M. and Zhang, C.L. 2003. Effect of silicon on growth of wheat. Emir. J. Food Agric., 19(2): 01-07.

Jackson, M.L. 1967. Soil chemical analysis, Pretence Hall of India. Pvt. Ltd. New Delhi, pp. 111-192.

Kadalli, G.G., Srirama, M.V. and Prakash, N.B. 2013. Determination of soluble silicon in soil $(0.01 \quad \mathrm{M} \quad \mathrm{CaCl} 2$ extractant). A Manual on soil and plant 
analysis, GKVK, Bengalore.

Kamenidou, S. and Toddy, J.C. 2008. Silicon supplements affect horticultural traits of greenhouse produced ornamental sunflowers. Hort. Sci., 43(1): 236-239.

Kamenidou, S., Cavins, T.J. and Marek, S. 2009. Evaluation of silicon asa nutritional supplement for green house zinnia production. Sci. Hort., 119(3): 297-301.

Kamenidou, S., Toddy, J.C. and Stephen, M. 2010.Silicon supplements affect floriculture quality traits and elemental nutrient concentrations of greenhouse produced gerbera. Scientia Hort., 123(3): 390-394.

Lalithya, K.A., Bhagya, H.P., Bharathi, K. and Hipparagi, K. 2014. Response of soil and foliar application of silicon and micro nutrients on leaf nutrient status of sapota. The Bioscan, 9(1): 159-162.

Lindasay, W.L. and Norwell, W.A. 1978. development of a DTPA soil test for zinc, iron, manganese and copper. Soil. Sci. Soc. Am. J., 42: 421-428.

Mary, B. 2005. The effect of calcium or silicon on potted miniature roses. M. Sc., Thesis, University of Louisiana at Lafayette. p. 98.

Matichenkov, V.V. and Bocharnikova, E.A. 2010. Technology for natural water protection against pollution from cultivated areas, 2020. 15 $5^{\text {th }}$ Annual Australian Agron. Conf., pp. 210 - 225.
Matoh, T.S., Murata and Takahashi, E. 1991. Effect of silicate application on photosynthesis of rice plants. J. Soil Sci. Plant Nutr., 62: 248-251.

Melo, S.P., Korndorfer, C.M., Korndorfer, G.H., Lana, R.M. and Santan, D.G. 2003. Silicon accumulation and water deficient tolerance in grasses. Scientia Agricola., 60: 755-759.

Milne, C.J.I., Laubscher, C.P.I. and Ndakidemi, P.A. 2012. The alleviation of salinity induced stress with applications of silicon in soilless grown Lactuca sativa L. 'Eish'. Int. J. Physical Sci., 7(5): 735 -742.

Prado, R.D.M. and Natale, W. 2005. Effect of application of calcium silicate on growth, nutritional status and dry matter production of passion fruit seedlings. Revista Brasileira de Engenharia Agricola eAmbiental, 9(2): 185-190.

Savvas, D. 2009. Effect of silicon and salinity on fruit yield and quality of tomato grown hydroponically. Acta. Hort., 609: 136-140.

Stamatakis, A., Papadantonakis, N., Simantiris, N., Kefalas, P. and Savvas, D. 2003. Effects of silicon and salinity on fruit yield and quality of tomato grown hydroponically. Acta. Hort., 609: 141-147.

Tucker, B.B. and Kurtz, L.T. 1960. Calcium and Magnesium Determinations by EDTA Titrations. SSSA J., 25(1): 27-29.

\section{How to cite this article:}

Kishore Kumar Das, G.S.K. Swamy, Debalina Biswas and Kuldeep Kumar Chnaniya. 2017. Response of Soil Application of Diatomaceous Earth as a Source of Silicon on Leaf Nutrient Status of Guava. Int.J.Curr.Microbiol.App.Sci. 6(4): 1394-1399.

doi: https://doi.org/10.20546/ijcmas.2017.604.170 